Journal of Universal Language 7

September 2006, 147-175

\title{
From Demonstratives to Copulas: A Cross-Linguistic Perspective and the Case of Polish*
}

\author{
Paweł Rutkowski \\ Warsaw University and Yale University
}

\begin{abstract}
This paper aims to clarify the syntactic status of the element to which appears in Polish copular expressions. The word to has recently been analyzed as a verb, see Linde-Usiekniewicz (2006); however, from the historical point of view, it clearly derives from a demonstrative pronoun. In the present article, I attempt to set the discussion of Polish to-constructions against a broader, crosslinguistic perspective. I provide an overview of a number of syntactic properties that characterize copulas derived from pronouns in other languages. I follow Li \& Thompson (1977) in assuming that a demonstrative may be (diachronically) reanalyzed as a copula
\end{abstract}

* For many helpful comments and suggestions, I would like to thank Maria Babyonyshev, Jadwiga Linde-Usiekniewicz, Paweł M. Nowak, Alexander M. Schenker, and Edward Stankiewicz. I am grateful to the Polish-American Fulbright Commission for the Junior Advanced Research Grant awarded for 2005-2006, thanks to which I was able to conduct my research at Yale University. This study was also partially supported by a dissertation grant from the Polish State Committee for Scientific Research (KBN), project number: 1H01D00429. 
148 From Demonstratives to Copulas: A Cross-Linguistic Perspective

if the nominal structure that precedes it changes its status from a leftdislocated topic to the subject of the whole copular expression. I conclude that this reanalysis has not yet taken place in Polish; therefore, I argue that the element to should not be interpreted as a copula.

Keywords: demonstrative pronouns, copulas, topicalization, leftdislocation, syntactic reanalysis

\section{Introduction}

There are two types of copular constructions in Polish. As shown in (1-2), both of them involve the use of the verb byc' 'be'; however, in one of them this verb is accompanied by the word to.

(1) Adam był lingwista.

Adam was linguist.INSTR ${ }^{2}$

'Adam was a linguist.'

(2) Adam to był lingwista.

Adam TO was linguist.NOM ${ }^{3}$

'Adam was a linguist.'

2 The following abbreviations are used in this paper:

$\begin{array}{lll}\text { COP-copula } & \text { NEUT-neuter } & \text { REFL-reflexive } \\ \text { DECL-PART-declarative particle } & \text { NOM-nominative } & \text { SING-singular } \\ \text { FEM-feminine } & \text { NOMIN-nominalizer } & \text { TOP-topical } \\ \text { GEN-genitive } & \text { NONTOP-nontopical } & \text { TopP-topic phrase } \\ \text { INSTR-instrumental } & \text { NP-noun phrase } & \text { TP-tense phrase } \\ \text { MASC-masculine } & \text { PL-plural } & \text { VP-verb phrase } \\ \text { NegP-negation phrase } & \text { PRON-pronoun } & \end{array}$

3 As illustrated in (1-2), the two constructions in question differ also in terms of case marking on the post-copular element (instrumental vs. nominative). In the present paper, I focus on structures such as (2); therefore, I will not analyze how the predicate instrumental is assinged/checked. For an extensive discussion of this phenomenon in some Slavic languages, see Franks (1995). 
The syntactic status of the precopular element to (historically, a demonstrative pronoun) has recently been subject to some debate. ${ }^{4}$ Citko (2006) analyzes it as a pronominal element residing in the head of Tense Phrase (TP), whilst Linde-Usiekniewicz (2006) argues that it is a defective verb which requires an auxiliary marked for tense and mood (note that typical Polish verbs inflect for number, person, tense, mood, and gender). ${ }^{5}$ In this article, I will argue that the properties of to-expressions can be accounted for by assuming that their development conforms to the universal mechanism of deriving copular elements from demonstrative pronouns. This diachronic change involves structural reanalysis and, arguably, simplification. However, it will be shown that the process in question has not been completed in Polish: the element to has not been reanalyzed as a copula, which makes the syntactic structure of Polish to-constructions more complex than that of their counterparts in languages such as Chinese.

\section{Pronouns as a Diachronic Source of Copular Elements}

Li \& Thompson (1977) argue that copular elements evolve from anaphoric pronouns in many languages. This development is possible if a topic-comment construction gets reanalyzed as a regular subject-predicate construction. These two stages can be illustrated as in (3) and (4), respectively:

\footnotetext{
4 Therefore, I adopt Linde-Usiekniewicz's (2006) convention of leaving to unglossed.

5 Polish is characterized by very rich inflection on both verbal and nominal elements. Note that the glosses of examples are not exhaustive in this paper. For ease of exposition, I will limit them to the most relevant information.
} 
150 From Demonstratives to Copulas: A Cross-Linguistic Perspective

(3) $\left[{ }_{\text {Topic }} \mathrm{NP} 1_{\mathrm{i}}\right]$ [Comment $\left.\mathrm{PRON}_{\mathrm{i}} \mathrm{NP} 2\right]^{6}$

(4) [Subject NP1] [Predicate COP NP2]

According to Li \& Thompson (1977), the pronoun in (3) acts as the syntactic subject of the comment clause. It is coreferential with NP1, a topicalized nominal construction. The topicalization analysis finds very clear confirmation in languages such as Saramaccan, in which copular constructions are structured as in (3). As shown by McWhorter 1997 and Whitman 2001, when the precopular position (NP1) is occupied by a third person pronoun, the pronoun must appear in the topic form:

(5) hen da di $\begin{aligned} & \text { gaama. } \\ & \text { he.TOP that } \\ & \text { 'He is the chief.' }\end{aligned}$
(6) ${ }^{* a}$ the da di
he.NONTOP that the

Li \& Thompson (1977) argue that, crosslinguistically, there are two options as far as what pronouns can appear in the base structure in (3). In the following examples from Palestinian Arabic (7) and Hebrew (8), the copular element is derived from a personal pronoun. ${ }^{7}$

\footnotetext{
${ }^{6}$ Here and below, I use the label NP (Noun Phrase) in a theory-neutral way: my goal is not to discuss whether the nominal elements which appear in copular constructions in the languages discussed in this paper are NPs or DPs (Determiner Phrases).

7 Throughout this paper, I follow the transcription conventions used by the authors of the articles from which I quote examples.
} 
(7) il rozzal huwwe usta:z mni:h. the man he teacher good 'The man is a good teacher.'

(8) david hu ha-ganav. David he the-thief 'David is the thief.'

Both huwwe and $h u$ mean 'he'; however, in sentences such as (7-8) they must be interpreted as copulas. The syntactic status of huwwe and $h u$ can no longer be pronominal because they may be combined with non-third-person elements, which means that they need not be coreferential with the topicalized element. Li \& Thompson (1977) illustrate this point with the following examples, in which huwwe and $h a$ (historically, third person pronouns) co-occur with firstperson subjects:

(9) ani hu ha-student še moše diber I he the-student that Moshe spoke itxa alev.

with.you about.him

'I am the student that Moshe told you about.'

(10) ana huwwe il usta:z alli fari:d Pallak Panno. I he the teacher that Fareed talked about.him 'I am the teacher that Fareed talked about.'

According to the model put forward by Li \& Thompson (1977), this is an example of diachronic syntactic reanalysis. The historical source of structure such as (7) might have been as follows: 'as for the man, he is a good teacher.'

Personal pronouns are not the only source of copulas. Demonstratives can also be used in the base structure shown in (3). 
152 From Demonstratives to Copulas: A Cross-Linguistic Perspective

Li \& Thompson (1977) illustrate this variant of diachronic development with examples such as (11) and (12), which come from Archaic Chinese (6th-5th century B.C.). The element shi is a demonstrative in both of them: in (11) it modifies the noun yè 'night', whilst in (12), it acts as the subject of the sentence (coreferential with the topicalized conjoined phrase qiong yù jiàn 'poverty and debasement'):

(11) shì yè yě, zhaò-mèn jī ž̀-xī míng. this night DECL-PART Zhao-men and Zi-xi ally 'This night, Zhao-men and Zi-xi formed an alliance.'

(12)

qíong yù jiàn, shì rén zhǐ sǔo poverty and debasement this people GEN NOMIN wù yě.

dislike DECL-PART

'Poverty and debasement, that is what people dislike.'

Example (12) corresponds to the topic-comment structure in (3). ${ }^{8}$ Li \& Thompson (1977) point out that shi ceases to function as a demonstrative in the late Han period: in sentences such as (13) (1st century A.D.), it is already a copula with no pronominal features.

8 Note that Bowern (2006) interprets such Archaic Chinese examples as cleft constructions. Apart from that, her account of the syntactic reanalysis that took place in Chinese is parallel to that proposed by Li \& Thompson (1977). She represents the input and output of the diachronic change in question in the following way (compare the structures in (3) and (4)):

$\begin{array}{ll}\text { (i) } \mathrm{X}, & \text { shì [be] } \mathrm{Y} \text { [input] } \\ \text { ' } \mathrm{X}, & \text { this [is] } \mathrm{Y} \text { ' }\end{array}$

(ii) $\mathrm{X}$ shi $\mathrm{Y}$ [output]

' $\mathrm{X}$ is $\mathrm{Y}$ ' 
(13) cǐ shì xiăo ér. this COP small child 'This is a small child.'

Note that the reanalyzed element shi becomes independent from the pronoun shi; therefore, we expect to find sentences in which they co-occur. This prediction finds confirmation in texts written as early as in the 2nd century B.C.: see example (14) (Peyraube \& Wiebusch 1994, Whitman 2001). ${ }^{9}$
(14) shì shì lie gui. this is violent ghost 'This is a violent ghost.'

Bowern (2006) gives a possible interpretation of the above reanalysis in terms of acquisition. She argues that what happened in the late Han period was that children started to parse shi as a verb and, on the basis of this parsing, deduced that the structure of expressions such as (12) must be as shown in (4) (in other words, the "misinterpretation" of shi drove a reanalysis of (3) as (4)). A similar account was put forward by Whitman (2001). According to his "relabeling hypothesis", syntactic reanalysis is caused by a change in the categorial feature of a head. Bowern (2006) rejects the opposite scenario, according to which children "expected an overt copula" and "recruited shi to fill that function".

Demonstratives gave rise to copulas in many natural languages (cf., Schuh 1983, Gildea 1993, Diessel 1999); Li \& Thompson (1977) provide examples of such a development in Hebrew:

\footnotetext{
${ }^{9}$ We do not find such examples in Modern Chinese because the element shi is no longer used as a pronoun.
} 
154 From Demonstratives to Copulas: A Cross-Linguistic Perspective

(15) moše ze student šeli.
Moshe that.MASC student my
'Moshe is a student of mine.'

They view the development of copulas from personal pronouns and demonstratives as two instances of the same general phenomenon. Diessel (1999) argues against this approach. He notices that the two patterns may sometimes differ with respect to morphosyntactic agreement. This is illustrated in (16-17) vs. (18). Diessel (1999) uses examples from Glinert (1989):

(16) ha-sha'on hu matana.

the-clock.MASC he present.FEM

'The clock is a present.'

(17) Hevrat bóing hi taagid

company.FEM Boeing she corporation.MASC

anaki.

giant.MASC

'The Boeing company is a giant corporation.'

In the above sentences, the copulas derived from personal pronouns clearly agree in gender with the precopular element. This is what $\mathrm{Li}$ \& Thompson's (1977) model predicts: the personal pronoun must resume the topicalized NP (compare the structure in (3)). However, as pointed out by Diessel (1999), the above agreement pattern does not apply to copulas which evolved from demonstratives:

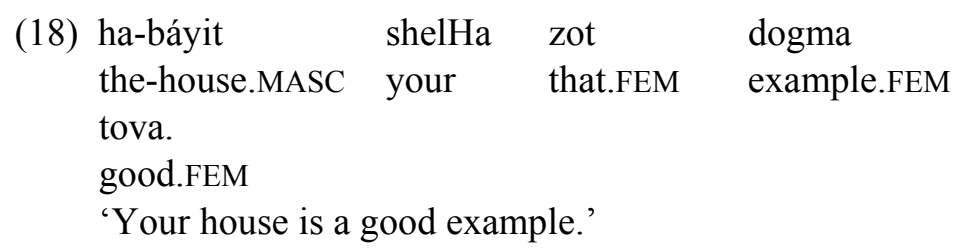


The demonstrative zot above agrees in gender with the following feminine noun dugma 'example', and not with the preceding masculine noun báyit 'house'. Therefore, Diessel (1999) proposes that copulas such as zot 'that.FEM' or ze 'that.MASC' derive from identificational demonstratives, i.e., non-anaphoric pronominal elements, in a way parallel to presentatives such as voila in French, ecce in Latin, vot in Russian, or oto in Polish. ${ }^{10}$ Diessel (1999) points out that, unlike the copulas in (16-17) (which evolved from anaphoric pronouns), a copula derived from an identificational demonstrative is not expected to have an antecedent; thus, it need not agree morphosyntactically with the preceding NP.

In the remaining part of this paper, I will follow Diessel's (1999) modification of Li \& Thompson's (1977) theory and try to apply it to Polish. As will be shown in the next section, the syntax of Polish to-expressions supports the prediction that, in copular contexts, demonstrative pronouns do not function as anaphoric elements and that it is NP2, and not NP1, that controls the copula. In section 4, I will argue that the structure of Polish constructions such as (2) is parallel to the representation in (3); it has not been reanalyzed as in (4) yet.

\section{Polish to-constructions: Crucial Generalizations}

As mentioned in the introduction, I assume that Polish has two types of copular constructions. The crucial difference between them is the presence/lack of the element to. See examples (1-2). Note that this view is not uncontroversial. Citko (2006) proposes a tripartite

\footnotetext{
${ }^{10}$ In some languages, identificational demonstratives differ from regular demonstratives morphologically. Diessel (1999) gives examples from Karanga, Supyire, Kilba, Nunggubuyu, and Ponapean, among others. In others, they can be defined on semantic grounds only.
} 
division: she distinguishes between verbal, pronominal, and dual copulas; they are illustrated in (19-21), respectively:

(19) Jan jest moim najlepszym przyjacielem. Jan is my best friend 'Jan is my best friend.'

(20) Jan to mój najlepszy przyjaciel. Jan TO my best friend 'Jan is my best friend.'

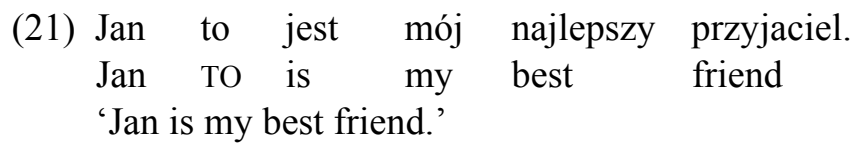

I follow Linde-Usiekniewicz (2006) in assuming that Citko's (2006) pronominal and dual copular constructions are two realizations of the same syntactic pattern: namely, structures such as (20) are derived from structures such as (21) by the deletion of the verb byc' 'be'. Note that this deletion is possible in the present tense only: ${ }^{11}$
(22) Jan to *(był) kiedyś mój najlepszy przyjaciel. Jan TO was once my best friend 'Jan was once my best friend.'

11 The lack of the copula byc' 'be' in the present tense is not surprising since structures corresponding to (21) are copula-less (in other words, consist of two noun phrases only) in many natural languages. According to $\mathrm{Li} \&$ Thompson (1977), the NP1 NP2 model is found for example in Kanuri (Nilo-Saharan), Isthmus Zapotec (Otomanguean), Djirbal (Australian), Luganda (Niger-CongoIjo), Classical Nahuatl (Uto-Aztecan), Wiyot (Algonquian), Naga (TibetoBurman), Jacaltec (Mayan) and almost all Austronesian languages. 
According to Citko (2006), both the verb być 'be' and the element to are copulas (which means that Polish allows two kinds of copulas). In principle, this approach is also advocated in LindeUsiekniewicz (2006), the difference being that in the latter analysis to is considered a verbal (and not pronominal) copula. However, Linde-Usiekniewicz's (2006) account differs from that proposed by Citko (2006) with respect to a very important observation, namely that the verbal element być 'be' in structures such as (21) agrees morphosyntactically with NP2, and not NP1; in LindeUsiekniewicz's (2006) terms, NP2 is the subject of to-expressions. She illustrates this fact with the following examples, in which there is clearly number agreement between the verbal copula and NP2:

(23) Dinozaury to jest gatunek gadów. dinosaurs TO is species reptiles.GEN 'Dinosaurs are a species of reptiles.'

(24) *Dinozaury to są gatunek gadów. dinosaurs TO are species reptiles.GEN

(25) Cyganeria to są artyści ... Bohemia to are artists

'Bohemia are the artists ...'

(26) *Cyganeria to jest artyści ... bohemia to is artists

I will refer to the fact that it is NP2 that triggers agreement on the verb być 'be' as "NP2-headedness". This property of tostructures is even more salient in the past tense, where the verb byc must agree with NP2 not only in number, but also in gender ${ }^{12}$ :

${ }^{12}$ Note that Polish verbs are not marked for gender in the present tense. 
158 From Demonstratives to Copulas: A Cross-Linguistic Perspective

(27)
Dinozaury to by
gatunek
gadów.
Dinosaurs TO was.MASC species.MASC reptiles.GEN 'Dinosaurs were a species of reptiles.'

(28)
Dinozaury to była
podgrupa
gadów.
Dinosaurs TO was.FEM subgroup.FEM reptiles.GEN 'Dinosaurs were a subgroup of reptiles.'

Examples (23-28) could also be used to illustrate another important observation made by Linde-Usiekniewicz (2006). Contra Citko (2006), she notices that there is no morphological agreement between NP1 and NP2. Consider the following examples:
(29) Jan to mój najlepszy przyjaciel. Jan TO my best.MASC friend.MASC 'John is my best friend.'
(30) Jan to straszna świnia. Jan TO terrible.FEM pig.FEM 'Jan is a real bastard.'

Linde-Usiekniewicz (2006) points out that the noun świnia 'bastard' (literally 'pig') is morphologically feminine in Polish but in (30) it is preceded by a masculine NP1 (Jan); thus, the fact that both NP1 and NP2 in (29) are masculine does not result from any morphosyntactic requirements, contrary to Citko's (2006) claim. I consider this line of reasoning very convincing. However, I do not share LindeUsiekniewicz's (2006) opinion concerning the issue of verbal agreement in sentences such as (30). She tentatively proposes that the verb in predicative to-structures (as opposed to regular NP2headed equatives such as (23), (25), or (27)) agrees in gender with NP1. She uses the following mixed-gender example to support this account: 

(31) Jan to był
straszna
świnia.
Jan TO was.MASC terrible.FEM pig.FEM
'Jan was a real bastard.'

I find Linde-Usiekniewicz's (2006) grammaticality judgment questionable in this case. According to my intuition, the masculine form of the copula być 'be' in (31) is far from felicitous. Example (32) seems more acceptable.
(32)
$\begin{array}{llll}\text { Jan } & \text { to } & \text { był } & \text { świnia. } \\ \text { Jan } & \text { TO } & \text { was.MASC } & \text { pig.MASC }\end{array}$
'Jan was a real bastard.'

However, I consider the word świnia 'bastard' (literally 'pig') in (32) a masculine noun. This assumption is based on Bańko's (2002) overview of mismatches between grammatical gender and natural gender in Polish. Some examples of such mismatches are listed in the following table (Bańko 2002: 150):

Table 1. Examples of Gender Mismatches in Polish ${ }^{13}$
\begin{tabular}{|c|c|c|}
\hline Example & Grammatical gender & Natural gender \\
\hline $\begin{array}{c}\text { babsztyl } \\
\text { 'cow } \\
\text { (about a woman)' }\end{array}$ & masculine & feminine \\
\hline $\begin{array}{c}\text { kociak } \\
\text { 'chick } \\
\text { (about a girl)' } \\
\text { (literally 'kitten') }\end{array}$ & masculine & feminine \\
\hline $\begin{array}{c}\text { kurwa męska } \\
\text { 'male prostitute' }\end{array}$ & feminine & masculine \\
\hline
\end{tabular}

\footnotetext{
${ }^{13}$ Bańko (2002) distinguishes three subclasses of masculine nouns (in other words, he assumes that there are three masculine genders in Polish) but this distinction is irrelevant to my analysis.
} 


\begin{tabular}{|c|c|c|}
\hline $\begin{array}{c}\text { babsko } \\
\text { 'old bag } \\
\text { (about a woman)' }\end{array}$ & neuter & feminine \\
\hline $\begin{array}{c}\text { oferma } \\
\text { 'loser' }\end{array}$ & $\begin{array}{c}\text { masculine or } \\
\text { feminine }\end{array}$ & $\begin{array}{c}\text { masculine or } \\
\text { feminine }\end{array}$ \\
\hline
\end{tabular}

Words such as oferma 'loser' are especially interesting because, from the morpho-syntactic point of view, they can function as either masculine or feminine nouns (both options allow two interpretations in terms of the sex of the referent, which means that grammatical gender is not related to natural gender):
(33) Ten cholerny oferma oblał egzamin. this.MASC damned.MASC loser failed.MASC exam 'This damned loser failed the exam.'
(34) Ta cholerna oferma oblała egzamin. this.FEM damned.FEM loser failed.FEM exam 'This damned loser failed the exam.'

However, a particular occurrence of nouns such as oferma 'loser' can have only one gender feature; in other words, it must trigger the same gender agreement on its modifiers and on the predicate:
(35)
*Ten cholerny oferma oblała egzamin. this.MASC damned.MASC loser failed.FEM exam
(36) ${ }^{*} \mathrm{Ta}$ cholerna oferma oblał egzamin. this.FEM damned.FEM loser failed.MASC exam

In my opinion, the noun świnia belongs to the same lexical class as oferma, which means that it triggers either masculine or feminine agreement. Thus, I argue that the masculine copula in (32) does not 
agree with NP1, but with NP2 świnia 'bastard', which is masculine in this case. On the other hand, (31) is not felicitous because the adjective straszna 'terrible' is clearly feminine. Note that example (31) becomes fully grammatical if the verb assumes the feminine form:
(37) Jan to była straszna świnia. Jan TO was.FEM terrible.FEM pig.FEM 'Jan was a real bastard.'

Therefore, I do not agree with Linde-Usiekniewicz's (2006) proposal that predicative $t o$-sentences such as (30) are N2-headed. If her account were on the right track, we should expect examples such as (39), (41), and (43) to be grammatical. However, it is not the case.
(38) Anna to był
głupi babsztyl.
Anna TO was.MASC stupid.MASC cow.MASC
'Anna was a stupid cow.'

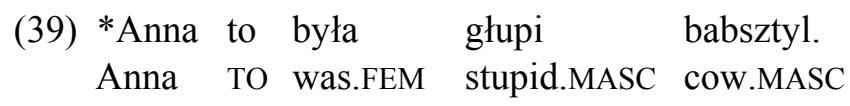

(40) Jan to była kurwa męska. Jan TO was.FEM whore.FEM male.FEM 'John was a male prostitute.'
(41) *Jan to był kurwa męska. Jan TO was.MASC whore.FEM male.FEM
(42) Wanda to było stare babsko. Wanda TO was.NEUT old.NEUT bag.NEUT 'Wanda was an old bag.'


162 From Demonstratives to Copulas: A Cross-Linguistic Perspective

(43)

$\begin{array}{lllll}\text { *Wanda } & \text { to } & \text { była } & \text { stare } & \text { babsko. } \\ \text { Wanda } & \text { TO } & \text { was.FEM } & \text { old.NEUT } & \text { bag.NEUT }\end{array}$

To sum up, I generally follow Linde-Usiekniewicz's (2006) observation that Polish to-structures are NP2-headed. Furthermore, I can see no reasons to assume that there are exceptions to this generalization. The fact that the copula verb być 'be' obligatorily agrees with NP2 can actually be considered one of the most characteristic features of to-construstions.

It should be noted that the NP2-headedness of Polish tostructures patterns with Diessel's (1999) observations concerning the syntactic properties of copulas derived from demonstratives. Another claim made by Diessel (1999) which finds support in Polish is that demonstratives in copular structures are not anaphoric. If the element to in constructions such as (20) is analyzed as a demonstrative, it definitely cannot be argued to resume NP1 because, as shown below, to is not a masculine form.

Table 2. Demonstrative 'this' in Polish

\begin{tabular}{|c|c|c|c|c|c|c|}
\hline \multirow{2}{*}{ Case } & \multicolumn{2}{|c|}{ Masculine } & \multicolumn{2}{c|}{ Feminine } & \multicolumn{2}{c|}{ Neuter } \\
\cline { 2 - 7 } & SING & PL & SING & PL & SING & PL \\
\hline Nominative & ten & ci & ta & te & to & te \\
\hline Genitive & tego & tych & tej & tych & tego & tych \\
\hline Dative & temu & tym & tej & tym & temu & tym \\
\hline Accusative & tego & tych & ta & te & to & te \\
\hline Locative & tym & tych & tej & tych & tym & tych \\
\hline Instrumental & tym & tymi & tą & tymi & tym & tymi \\
\hline
\end{tabular}

Therefore, I follow Diessel's (1999) line of reasoning and assume that to is an identificational demonstrative. This approach finds confirmation in the fact that, as pointed out by LindeUsiekniewicz (2006), biphrasal copular constructions of the form 
NP1 to być NP2 are essentially parallel to examples such as (44-45):
(44) To (jest) mój najlepszy przyjaciel.
TO is my best friend

'This is my best friend.'

As indicated by gender agreement, identificational $t o$-structures are NP2-headed (similarly to copular phrases such as (20-21)):
(45) $\mathrm{T}$
TO was.MASC my best friend.MASC
'This was my best (male) friend.'
(46) To była moja najlepsza przyjaciółka.
TO was.FEM my best friend.FEM
'This was my best (female) friend.'

Therefore, I conclude that there are good reasons to treat structures such as (44) as the cognitive source of constructions shown in (20-21), which, in turn, means that Diessel's (1999) diachronic model is applicable to Polish.

\section{The Syntax of the Demonstrative-to-copula Evolution}

In this section, I attempt to rephrase the above observations on Polish to-expressions in a generative syntactic framework. I propose that, in sentences such as (21-22), NP1 is an external (left dislocated) topic, whereas the element to resides in the sentential subject position (the specifier of TP). Following Whitman (2001), I assume that the left dislocated phrase is located in the specifier of 
Topic Phrase, a layer projected above TP. NP1 has to be nominative because this is the default case value in Polish, assigned when a nominal element is placed outside of any syntactic context. I further argue that the verb być 'be' is the only copula in such structures. ${ }^{14}$ The surface position of this copula in examples such as (21-22) results from movement: the verb rises to a functional projection located above VP (but, crucially, below TP). I leave the exact mechanism of this raising for further investigation. The base structure of Polish to-sentences is illustrated in (49).

I view NP2 as a VP-internal subject. Hence, it is this element that the verb agrees with. On the other hand, the element to is a place holder for the sentential subject. The proposal that the sentential subject position is not occupied by an NP explains why neither NP1 nor NP2 can act as the controller of a participial phrase. Note the following contrast:

(47) Adam był lingwista, mieszkając w New Haven. Adam was linguist living in New Haven 'Adam was a linguist when he lived in New Haven.'

(48) *Adam to był lingwista, mieszkając w New Haven. Adam TO was linguist living in New Haven

In (48), as opposed to the regular ("non-to") copular structure in (47), the phrase Adam is not located in the sentential subject position, therefore it cannot act as the subject of the participial phrase mieszkajac w New Haven 'living in New Haven'

\footnotetext{
${ }^{14}$ Li \& Thompson (1977) point out that one of characteristic features of most IndoEuropean, Finno-Ugric, and Altaic languages is that copulas are usually verbs.
} 
(49)
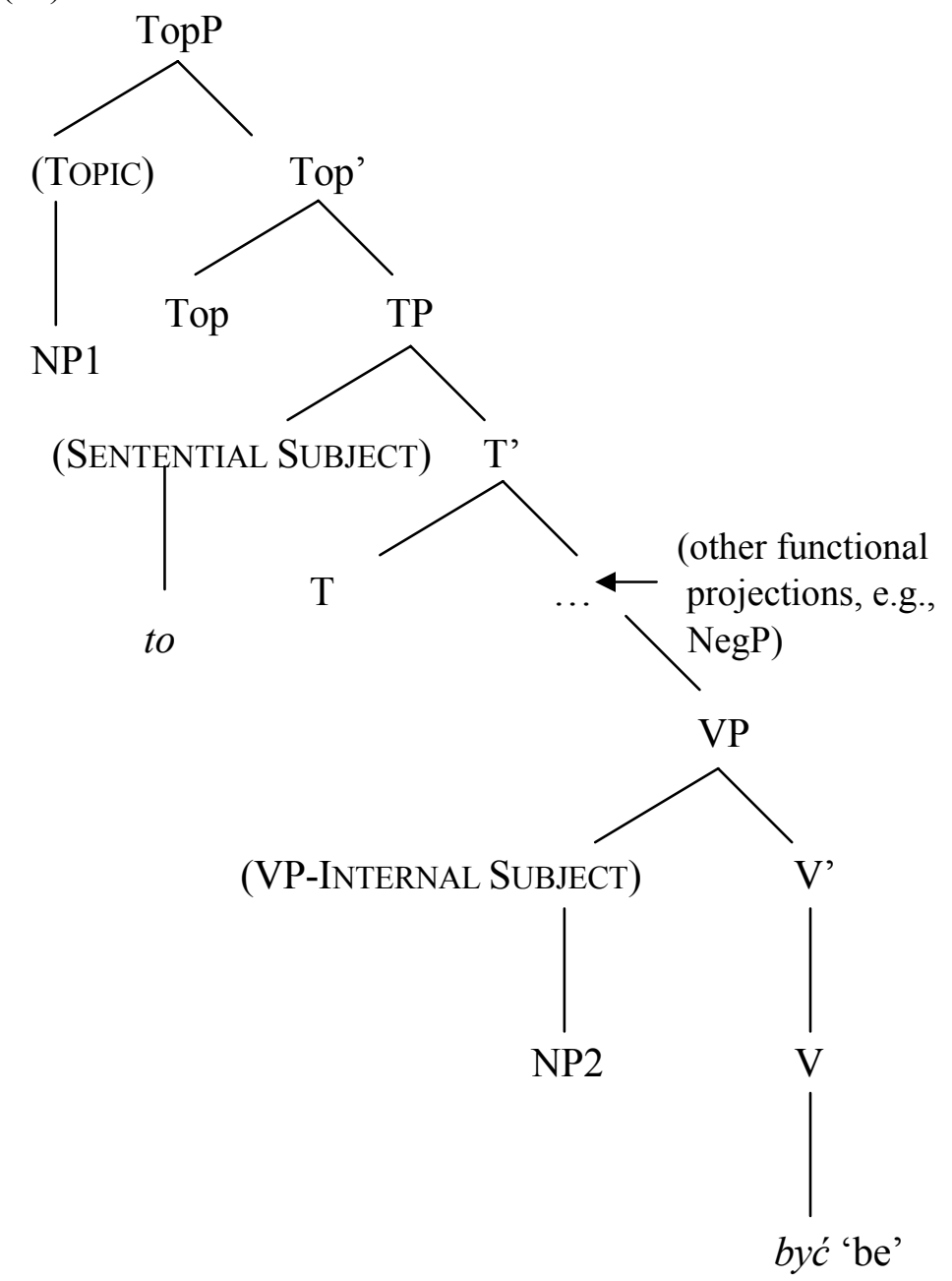

Interestingly, Citko (2006) admits that a left dislocation analysis would be "intuitively very plausible". Nonetheless, she rejects it on the basis of the fact that quantified elements can take the position of 
166 From Demonstratives to Copulas: A Cross-Linguistic Perspective

NP1 in copular expressions, although they are normally excluded from left dislocation structures. Compare (50) and (51).

(50) Każdy student to (jest) potencjalny profesor. every student TO is potential professor 'Every student is a potential professor.'

(51) *Każdy student, on jest potencjalnym profesorem. every student he is potential professor

This argument is problematic because Polish does not seem to allow resumptive personal pronouns in left dislocation structures at all, even if the left dislocated nominal expression is not quantified:

(52) ?*Adam, on jest potencjalnym profesorem. Adam he is potential professor 'Adam, he is a potential professor.'

What is used in left dislocation constructions is precisely the element to, and not a resumptive pronoun:

(53) Adam, to dopiero jest potencjalny profesor. Adam TO only is potential professor 'Adam, he really is a potential professor.'

Therefore, I do not find Citko's (2006) argumentation convincing.

The topicalization analysis shown in (49) finds confirmation in an interesting phenomenon discussed by Whitman (2001). He points out that predicate fronting over a topicalized or left dislocated element results in ungrammaticality (because it violates Relativized Minimality). He illustrates this point with the following example (Note that my father is a left dislocated element): 
(54) *Smart, my father he is.

Whitman (2001) reports that, as shown by McWhorter (1997), this generalization is supported by the following data from Saramaccan:

(55) disi da mi tata. this that my father 'This is my father.'

(56) *mi tata, disi da. my father this that

Predicate fronting is impossible in (56) because the pre-copular element disi is topicalized due to its status as NP1 in a topiccomment copular construction. Interestingly, a parallel phenomenon can be observed in Polish to-structures:

(57) Adam to mój przyjaciel od niepamiętnych czasów. Adam TO my friend since immemorial times 'Adam has been a friend of mine since time immemorial.'

(58) *Mój przyjaciel Adam to od niepamiętnych czasów. my friend Adam TO since immemorial times

This suggests that the topicalization analysis of Polish toexpressions illustrated in (49) is on the right track. Note also that predicate fronting is not ungrammatical in regular copular constructions (i.e., those that do not involve the use of the element to): 
168 From Demonstratives to Copulas: A Cross-Linguistic Perspective

(59) Adam jest moim przyjacielem od niepamiętnych Adam is my friend since immemorial czasów. times

'Adam has been a friend of mine since time immemorial.'

(60) Moim przyjacielem Adam jest od niepamiętnych my friend Adam is since immemorial czasów. times

'Adam has been a friend of mine since time immemorial.'

Note that the structure I argue for is different from that schematized in (4). In other words, Polish is different from Modern Chinese because it has not undergone the pronoun-to-copula reanalysis. In a way, the situation in Polish could be compared to that in Wappo (a Native American language spoken in California). According to Li \& Thompson (1977), the reanalysis of the Wappo pronominal element $c e$ as a copula has not yet been completed. One of their arguments is that ce cannot be used both as a demonstrative and copula. Compare (61) and (62).
(61) ?i ce?(-e?) teme? Rek'a.
I that-COP his child
'I am his child.'
(62) *ce ce?(-e?) teme? ?ek'a. that that-COP his child
'That is his child.'

The same is true of Polish: 


\section{(63) *To to jest mój najlepszy przyjaciel. this TO is my best friend \\ 'This is my best friend.'}

The case of Wappo is especially interesting because the copular element includes not only a demonstrative (ce), but also the morpheme $e$ ? that can be optionally elided. Li and Thompson 1977 argue that the optional element must be an older copula, whose function has been gradually taken over by the demonstrative $c e$. This development might be what will happen to Polish toconstructions in the future: the element to may take over the copular function of the verb byc 'be'. This, however, has not taken place yet.

Linde-Usiekniewicz (2006) argues for analyzing the element to as a verbal copula, and not a pronominal element. She draws a parallel between to and defective verbs such as warto 'be worth' or trzeba 'be necessary'. Being morphologically invariant, they are assumed to inflect for tense and mood by means of taking an appropriate form of the auxiliary verb byc 'be' (note that this verb is not required in the present tense). ${ }^{15}$ This is illustrated below:
(64) Warto
(jest) tam pójść.
be.worth is there go
'It is worth to go there.'
(65) Warto
było tam
pójść.
be.worth
was there
go
'It was worth to go there.'

\footnotetext{
${ }^{15}$ Elements such as trzeba 'it is necessary' were analyzed as verbs by Saloni (1974). I will not discuss the details of his proposal here because, as I will show below, the element to does not seem to belong to the same syntactic class as Saloni's (1974) defective verbs.
} 
(66) Warto byłoby tam pójść. be.worth would there go 'It would be worth to go there.'

According to Linde-Usiekniewicz (2006), the only major difference between to and defective verbs is that the latter are subject-less. Therefore, she proposes that these two classes belong to the same lexical category. In other words, examples such as (64-66) are assumed to be syntactically parallel to copular constructions such as (67):

(67) Waterloo to było zwycięstwo.

Waterloo TO was victory

'Waterloo was a victory.'

This analysis seems to be questioned by the fact that expressions such as warto byto 'it was worth' in (65) and to byto 'TO was' in (67) differ significantly in terms of their internal structure. As shown below, to-constructions always "bracket" elements such as negation markers - (68), adverbs - (70), or modal verbs - (72) and (74). Complex verbal constructions are also admitted in between to and the verb byc' 'be'-(76).

(68) Waterloo to nie było zwycięstwo.

Waterloo TO not was victory

'Waterloo was not a victory.'

(69) *Waterloo nie to było zwycięstwo.

Waterloo not TO was victory

(70) Waterloo to oczywiście było zwycięstwo.

Waterloo TO obviously was victory

'Waterloo was obviously a victory.' 
(71) *Waterloo oczywiście to było zwycięstwo. Waterloo obviously TO was victory

(72) Waterloo to mogło być zwycięstwo. Waterloo TO could be victory 'Waterloo could be a victory.'

(73) *Waterloo mogło to być zwycięstwo. Waterloo could TO be victory

(74) Waterloo to powinno było być zwycięstwo. Waterloo TO should was be victory 'Waterloo should have been a victory.'

(75) *Waterloo powinno było to być zwycięstwo. Waterloo should was TO be victory

(76) Waterloo to wydaje się być zwycięstwo. Waterloo TO seems REFL be victory 'Waterloo seems to be a victory.'

(77) *Waterloo wydaje się to być zwycięstwo. Waterloo seems REFL TO be victory

Defective verbs such as warto 'be worth' do not conform to this pattern. The auxiliary verb być 'be' is usually placed immediately after the defective verb:

(78) Nie warto było tam pójść.

not be.worth was there go

'It was not worth to go there.' 
172 From Demonstratives to Copulas: A Cross-Linguistic Perspective

(79) *Warto nie było tam pójść.
be.worth not was there go

The data in (68-77) seem to pattern with the assumption that the element to and the verbal copula byc' 'be' are base generated in two different (and distant syntactically) positions - compare the structure in (49).

It also seems that Linde-Usiekniewicz's (2006) analysis of to as a verb runs into trouble when confronted with examples such as the following:

(80) Amor to znaczy "miłość". amor TO means love

'Amor means "love".'

(81) Dwa plus dwa to się równa cztery. two plus two TO REFL equals four 'Two plus two equals four.'

(82) Adam to staje się coraz Adam TO becomes REFL more.and.more bigger pierdoła. old-fart

'Adam is becoming more and more of an old fart.'

All the above sentences conform to the to-pattern, which could be schematized in the following way:

(83) NP1 TO VERB NP2

Therefore, it is plausible to analyze them on a par with copular expressions such as (20-21). However, if Linde-Usiekniewicz's (2006) proposal were applied to constructions such (80-82), the 
verbs znaczyć 'mean', równać się 'equal', stawać się 'become' would have to be analyzed as auxiliaries attached to the main verb to (which seems to be an undesirable conclusion from the semantic point of view).

Interestingly, the Polish to-structure exemplified in (44-46) has an exact parallel in German. Similarly to to in Polish, the German word das in structures such as (84-85), taken from Diessel (1999), derives from a neuter demonstrative. However, it differs from regular demonstratives because it never inflects; in other words, it does not agree in gender or number with the following NP.

(84) Das ist meine schwester.
this.NEUT is my
'This is my sister.'

(85) Das sind meine freunde. this.NEUT are my friends.MASC 'These are my friends.'

If we applied Linde-Usiekniewicz's (2006) analysis to the above German data, we would have to say that das is a copular verb. However, Diessel's (1999) comparative survey shows that das should rather be interpreted as an identificational demonstrative. Although Diessel (1999) argues that such demonstratives often give rise to copulas (see Section 2 of the present paper), there seems to be no reason to claim that this development has taken place in German. In identifying constructions (such as (84-85)), the demonstrative das is always accompanied by a copula verb sein 'be'. On the other hand, das never appears in regular copular expressions of the type NP sein 'be' NP. Thus, I conclude that the only copular element in German is the verb sein. 
174 From Demonstratives to Copulas: A Cross-Linguistic Perspective

\section{Conclusion}

In this paper, I have discussed the issue of pronoun-to-copula development and the syntax of Polish to-expressions, i.e., copular constructions which involve the use of the element to. Historically, to is a demonstrative pronoun. I have shown, that this status is reflected in the syntactic properties of to-expressions (note that these properties pattern with certain assumptions of Diessel's (1999) cross-linguistic model). I have also proposed a generative analysis of the structure of to-expressions. The crucial assumption of this proposal is that NP1 is a left dislocated phrase, whereas NP2 is a VP-internal subject.

\section{References}

Bańko, M. 2002. Wyktady z Polskiej Fleksji. Warszawa: Wydawnictwo Naukowe PWN.

Bowern, C. 2006. Syntactic Change and Syntactic Borrowing in Generative Grammar. Manuscript, Houston, TX: Rice University.

Citko, B. 2006. Small Clauses Reconsidered: Not So Small and not All Alike. Manuscript, Seattle, WA: University of Washington.

Diessel, H. 1999. The Morphosyntax of Demonstratives in Synchrony and Diachrony. Linguistic Typology 3, 1-49.

Franks, S. 1995. Parameters of Slavic Morphosyntax. Oxford: Oxford University Press.

Gildea, S. 1993. The Development of Tense Markers from Demonstrative Pronouns in Panare (Cariban). Studies in Language 17, 53-73.

Glinert, L. 1989. The Grammar of Modern Hebrew. Cambridge: Cambridge University Press.

Li, C. \& S. Thompson. 1977. A Mechanism for the Development of Copula Morphemes. In C. Li (ed.), Mechanisms of Syntactic Change 419-444. 
Austin, TX: University of Texas Press.

Linde-Usiekniewicz, J. 2006. Small Clauses Reconsidered. Manuscript, Warsaw: Warsaw University.

McWhorter, J. 1997. Towards a New Model of Creole Genesis. New York: Peter Lang.

Peyraube, A. \& T. Wiesbusch. 1994. Problems Relating to the History of Different Copulas in Ancient Chinese. In M. Chen \& O. Tzeng (eds.), In Honor of William S-Y. Wang: Interdisciplinary Studies on Language and Language Change 383-404. Taipei: Pyramid Press.

Saloni, Z. 1974. Klasyfikacja Gramatyczna Leksemów Polskich. Język Polski 54.1, 3-13 \& 54.2, 93-101.

Schuh, R. 1983. Kilba Equational Sentences. Studies in African Linguistics 14, 311-326.

Whitman, J. 2001. Relabelling. In S. Pintzuk, G. Tsoulas, \& A. Warner (eds.), Diachronic Syntax: Models and Mechanisms 220-238. Oxford: Oxford University Press. 